\title{
Exploring teachers' use of technology in teaching and learning mathematics in KwaZulu-Natal schools
}

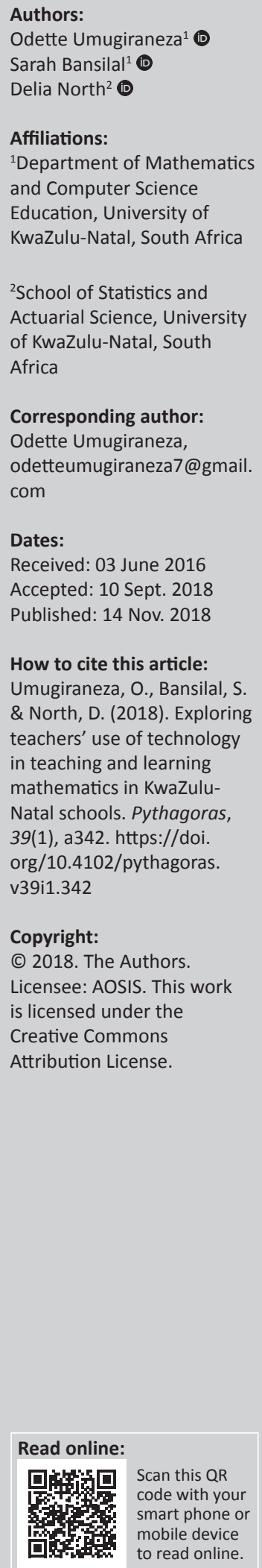

\begin{abstract}
It is often claimed that technology can be used as a tool that can facilitate teaching and learning and contribute to learners' achievement. This article reports on a study about how KwaZulu-Natal mathematics teachers use, access and integrate technology in the teaching and learning of mathematics. A questionnaire containing closed and Likert scale questions regarding the use of technology, was distributed to $75 \mathrm{KwaZulu}-\mathrm{Natal}$ mathematics teachers. The findings reveal that the technology used most commonly by the group for teaching mathematics is calculators. Almost all the teachers reported that they never use computers in their teaching of mathematics. Although the teachers reported that they do not use computers in teaching and learning, about $80 \%$ of the participants conveyed a positive view that using technology improves learners' understanding of mathematics. The findings further indicate that the teachers' propensity to use technology in instructional practice is associated with demographic factors related to teaching experience, gender, level of study and participation in professional learning activities. The study also showed that teachers who have access to internet instructional resources have higher levels of confidence in teaching mathematics and hold broader beliefs about the nature of mathematics and the aims of teaching mathematics than the teachers who do not use the internet for instructional purposes.
\end{abstract}

\section{Introduction}

The rapidly growing influence of technology in the 21st century has led to calls for teaching and learning to be transformed to prepare learners to compete within the global knowledge economy. Learning in the 21st century requires the collaboration of well-trained teachers, working in well-equipped classrooms and using technology innovatively to support a constructive learning atmosphere (Molnár, 2008). Technology allows learners to move beyond focusing on basic information to more global issues by providing them with access to innovative applications and tools (Van Melle \& Tomalty, 2000). The teaching environment can thus be transformed by teachers if they integrate technology effectively in preparing lessons, designing learning activities and conducting assessments.

The potential of technology to transform the classroom is recognised by the South African Department of Education (DOE) which supports the idea of introducing Information and Communication Technology (ICT) in South African schools (Department of Basic Education [DBE], 2016; DOE, 2007). Teachers are urged to develop learners with 'relevant modern skills that match the needs of our changing world' (DBE, 2016, p. 3). Learners should be able to 'access, analyse, evaluate, integrate, present and communicate information; create knowledge and new information by adapting, applying, designing, inventing and authoring; and function effectively in a knowledge society by using appropriate ICT ... skills' (DOE, 2007, p. 3). The education department states that ICT can recreate a classroom atmosphere while also advancing higher-order thinking skills in learners (DBE, 2010). For example, it enables teachers and learners to increase the level of comprehension, reasoning, problem-solving, thinking and employability (DOE, 2004, 2007). The DOE further highlights five targets of the use of ICT which involve 'entry (basic ICT skills), adoption and adaptation (integration of ICT in teaching and learning), and appropriations and innovation (specialisation and innovation in ICT education)' (DOE, 2007, p. 9).

Thus, teachers are encouraged to develop their capability and innovation to make the best use of the potential of digital devices in augmenting learner performance (Ndlovu \& Lawrence, 2012). It has become incumbent upon teachers to attain relevant and appropriate ICT knowledge and skills to be able to integrate it appropriately in teaching, learning and administration (DOE, 2007). However, the digital divide, which is the disparity in the level of development of and access to ICT between different sectors, presents a challenge to educational innovations. Insufficient basic 
ICT infrastructure in rural schools poses a challenge for teachers, which is not necessarily the case in urban schools (Dzansi \& Amedzo, 2014). Ndlovu and Lawrence (2012) emphasise that ICT policy has been poorly implemented across South African schools, more specifically for those schools that serve disadvantaged areas, thus adding to the digital divide. Many disadvantaged schools cannot keep up with the well-resourced schools in terms of integrating ICT into their teaching and learning approaches. The limited use of ICT is not simply caused by the shortage of resources, but it is dependent on the ways in which the teachers utilise the available educational tools in their teaching (Ndlovu \& Lawrence, 2012). Research highlights particular teacher factors such as age, experience, confidence, beliefs, as well as gender which seem to influence the extent to which teachers take up technology in their teaching practices (Ali, 2015; Beswick, 2007; Brändström, 2011; Cavas, Cavas, Karaoglan, \& Kisla, 2009; Choi, 1992).

This article addresses the use of technology in teaching mathematics and statistics. Recent advances in technology have unlocked entirely new directions for education research. In this study, we try to make a contribution towards finding out more about the use of technology in KwaZulu-Natal schools. The study also explores the relationship between teachers' use of technology and their confidence and beliefs about the ways in which mathematics should be taught. To our knowledge, no previous study has focused on these issues. Furthermore, the study looks at some factors that may have a relationship with the use of technology. It is hoped that the knowledge contributed by this study will help the education department in their planning and provision for teacher support in the use of technology. We also hope that this study will help other researchers identify areas in the field of mathematics teachers' use of technology which need more attention.

\section{Literature review}

The integration of technology in teaching and learning is not intended to replace traditional methods, but to support schools to improve teaching and learning (Tishkovskaya \& Lancaster, 2012). Some technology tools include 'power points, web-based games, the internet, projectors, smart boards, Elmos, calculators, videos, DVDs and music' (Moore, 2012).

The GAISE College Report (GAISE College Report ASA Revision Committee, 2016) includes graphical calculators, statistical software packages, educational software, applets, spreadsheets, classroom response systems, web-based statistics related resources, data repositories, online texts, and data analysis routines in their list of recommended technology tools.

ICTs, especially computers and internet technologies, support new ways of teaching and learning rather than simply allowing teachers and students to do what they have done before in a better way (Noor-Ul-Amin, 2013). However, for teaching and learning to improve, technologies must be used as cognitive tools for learning and not simply as an alternative delivery platform (Herrington, Reeves, \& Oliver, 2010). Moore (2012, p. 14) reports that integrating technology in a mathematics classroom can promote the development of computational skills while also developing higher order mathematical skills. The view of Forster (2006) is that using technological tools can improve the learning of mathematics by allowing learners to pay attention to underlying properties and relationships instead of focusing on tedious complicated calculations that may sometimes detract from the intended outcomes. ICT provides opportunities for learning by helping learners to access, spread, renovate and share ideas and information, which is transmitted in integrated communication styles and designs.

Technological tools can also open up access to a wider variety of problem-solving strategies than those limited to paper and pencil strategies (Bansilal, 2015).

Tools such as online videos allow the students to vary the pace at which they can learn new material in mathematics (Bansilal, 2015). By providing access to different representations that help visualisation of mathematical objects, certain mathematics software can contribute to a deeper understanding of the concepts. Technology also opens up possibilities for developing statistical concepts by enabling the visualisation of the concepts (Sorto \& Lesser, 2009); it can make the demonstration of complex abstract ideas easier while also providing multiple examples (Chance, Ben-Zvi, Garfield, \& Medina, 2007). In teaching statistics, technology can aid students in learning to think statistically by facilitating access to real (and often large) data sets and fostering active learning. Thus it can allow a learner to explore concepts and analyse data, manage and visualise data, perform inference, and check conditions that underlie inference procedures (GAISE College Report ASA Revision Committee, 2016).

Purcell, Heaps, Buchanan and Friedrich (2013) describe the importance of internet and digital tools in teachers' work of teaching. They state that 'the greatest impact of the internet and other digital tools on their role as teachers has been access to more content and material for use in the classroom and a greater ability to keep up with developments in their field' (p. 51). Noor-Ul-Amin (2013) argues that networked computers with internet connectivity can increase learner motivation as it combines the media richness and interactivity of other ICTs with the opportunity to connect with real people and to participate in real world events. Kramarski and Feldman (2000) report that instruction that integrates the use of the internet in classrooms improves learners' motivation in learning and has positive effects on learners' reading comprehension. Brändström (2011) examined the influence of the use of the internet on planning and instruction by interviewing five upper secondary school teachers. The findings revealed that the teachers consider the internet as a valuable source of information and an important additional teaching tool. It also reduces teachers' work while facilitating quick exchanges (Higgins, 2003). 
Some studies have reported that the use of technology also increases teachers' confidence in the content (Brändström, 2011; Buabeng-Andoh, 2012; Cassim, 2010; Cox, Preston, \& Cox, 1999; Leendertz, Blignaut, Nieuwoudt, Els, \& Ellis, 2013; Mumtaz, 2000; O'Dwyer, Russell, \& Bebell, 2003; Remesh, 2013; Sabzian \& Gilakjani, 2013; Yang, 2013). For instance, in Cox et al.'s (1999) study, teachers reported that using ICT increased their confidence. O'Dwyer et al. (2003) further found that higher teacher confidence is associated with the largest increased use for delivering instruction and, in particular, increased use for class preparation. Further findings showed a significant relationship between teachers' confidence and ICT applications (Albion, Jamieson-Proctor, \& Finger, 2011; Tasir, Abour, Halim, \& Harun, 2012).

Research conducted in South Africa reports that the use of computers tends to feature fairly extensively in the learning areas of language and mathematics, natural sciences and technology, and less in humanities and arts (Lundall \& Howell, 2000). On the one hand, they found that in Grades 1 to 7 computers tend to be used mainly for drill and practice and problem-solving exercises; on the other hand, from Grade 8 upwards computers tend to be used for a greater variety of purposes in the teaching and learning process. They also mention that drill and practice exercises, although less prominent, continue to be used in Grades 8 to 12 .

Leendertz et al. (2013) investigated the level of technological pedagogical content knowledge (TPACK) of mathematics teachers and how TPACK contributes towards more effective Grade 8 mathematics teaching in South African schools. Their findings indicate that, with the improvement of TPACK of mathematics teachers, their confidence increases in their ability to apply technology for teaching mathematics in South African schools. Teachers acknowledged that ICT promotes conversations with colleagues and peers regarding teaching and learning practices and gives a platform to express their teaching and learning accomplishments. ICT also enabled them to conduct their administrative work more efficiently, allowed them to facilitate interactive lessons, and promoted confidence in using a variety of teaching and learning strategies designed for teaching (Leendertz et al., 2013).

Sometimes the failure by teachers to integrate technology in their classrooms is because of problems that are beyond their control (Marwan, 2008; Mumtaz, 2000). Some challenges experienced by teachers when trying to implement ICT include insufficient ability of ICT specialist teachers to teach students computer skills, lack of computer accessibility, lack of time as well as lack of financial support (Mumtaz, 2000). Similarly, Buabeng-Andoh (2012) identified poor ICT skills, low teacher confidence, insufficient pedagogical teacher training, absence of suitable educational software, limited access to ICT, inflexible structure of traditional education systems as well as limiting curricula design as some of the reasons that inhibited take-up of technology by teachers. The application of technology in teaching can lead to complexity because of the demands of learning newer technologies (Koehler \& Mishra, 2009). Cavanagh, Reynolds and Romanoski (2004) examined how the ICT learning culture reconciles student learning and curriculum implementation in the classroom. In their study, they found that students expressed high confidence in their capacity to use ICT in their learning, but teachers were uncertain about the extent to which the learning was sustained by the learners.

Teachers' beliefs about teaching and learning play a major role in their decisions about how to teach the content. Hollingsworth (1989) articulated that the way teachers implement new methods or programmes in their classrooms relates to whether teachers' beliefs correspond with the suggested new methods. Ernest (1989) emphasises the important role of teachers' beliefs, particularly in mathematics education, where these beliefs depend on individual teachers. Ernest argues that teachers have particular beliefs about the nature of mathematics and how it is best taught. For instance, beliefs that mathematics is computation stems from ideas about the nature of mathematics whereas beliefs that teaching mathematics should be shaped by alternative ideas stem from beliefs about teaching mathematics. Beswick, Callingham and Watson (2012) found that while some teachers agreed that mathematics is the same as computations and that telling learners the answer is an efficient way of facilitating their mathematics learning, other teachers of mathematics believe they should be involved with learners' thinking. Beswick et al. are of the view that teacher's beliefs about general principles related to the nature of mathematics, and the learning and teaching of mathematics (rather than the use of specific approaches), are what matter to student learning.

Several studies have focused on teachers' beliefs about technology (Cavas et al., 2009; Choi, 1992; Mueller, Wood, Willoughby, Ross, \& Specht, 2008; O'Dwyer et al., 2005) as a factor that motivates teachers' use of technology. Some studies found a significant relationship between teachers' beliefs towards technology and their instructional technology practices (Ali, 2015; Mumtaz, 2000; Palak \& Walls, 2009).

Further factors that have been explored with respect to teachers' use of ICT are gender and age. The findings of Choi (1992) revealed that females and young teachers hold a slightly higher computer literacy level than male teachers and older teachers. However, the older age group tended to have more positive attitudes toward the instructional use of microcomputers in comparison with the younger age groups. However, the results of the study indicated no relationship between the teachers' attitudes and their knowledge of microcomputers. On the other hand, Almekhlafi and Almeqdadi (2010) found that male teachers were more likely to use technology than female teachers. Gender and age were also discussed by Cavas et al. (2009) who found that Turkish science teachers' attitudes towards ICT did not differ regarding gender, but differed regarding age, computer ownership at home and computer experience. These authors state that factors influencing the use of technology include 
availability of computers in the classroom, sharing of resources, a supportive administration, strong support staff, environmental, personal, social and curricular issues. Similar findings indicated that school factors, personal factors as well as beliefs towards technology influence teachers' use of technology (Cubukcuoglu, 2013; Mumtaz, 2000). Mumtaz (2000) identified an important technical sustenance of 20 hours per week that was necessary for teachers and found that a positive attitude of the principal contributed to teachers' use of technology. These authors agree it is important to support teachers in using technology in teaching and learning.

Sabzian and Gilakjani (2013) identified two contributing factors to teachers' low self-confidence in using technology. The authors found that limited computer instruction could lead to teachers' low confidence level when they initiate computer activities and result in high anxiety about using computers. The second was poor motivation which could result in insufficient knowledge in using instructional technology even if computers are provided in the classroom for teaching and learning. Ali (2015) points out that teachers' poor knowledge in using technology may be due to a lack of professional training with computers and lack of teachercentred experiences in education and the lack of technological devices. These studies emphasise the need for programmes that can provide effective computer instruction to teachers while also helping them gain experience in the use of the technological tools.

Using factor analysis, Leendertz, Blignaut, Ellis and Nieuwoudt (2015) validated a questionnaire for ICT development of mathematics teachers. They found that the first factor was related to 'teachers'expectation' (reliability of 0.92), which means that mathematics teachers expect the DOE, provincial departments and schools to work together to improve an ICT strategic plan in order to increase technology use. Based on their study, they emphasise that professional development courses are urgently needed to support teachers in integrating ICT into teaching and learning. The site of the training does not have to be confined to the school as Lundall and Howell (2000) point out that many schools indicated that some teachers have access to technology-related professional training opportunities that take place outside the school.

This article addresses the use of technology in teaching mathematic in KwaZulu-Natal schools. As illustrated by the literature, recent advances in technology have unlocked entirely new directions for education research and we briefly surveyed some of the more pertinent studies in this area. We first looked at the ways in which digital classrooms support students' learning, before moving to the use of particular tools for instruction such as the internet which is a focus of this study. We then reviewed studies that investigated the association between using technology and particular demographic factors. The literature review also included studies about challenges faced by teachers in trying to increase the use of ICT in their classrooms. This review serves as a useful foundation to look at the use of technology by a group of KwaZulu-Natal mathematics teachers, and to identify the factors that are associated with it.

\section{Research design and methodology}

This quantitative study is a part of a larger doctoral study by the first author, developed to investigate teachers' knowledge of, beliefs about and confidence in teaching mathematics (Umugiraneza, Bansilal, \& North, 2016, 2017, 2018a, 2018b). Knowledge and skills in appropriate technological tools explored in this study are recognised as a part of the knowledge required to teach these concepts. The participants in this quantitative study were 75 mathematics teachers from Grades 4 to 12 from KwaZulu-Natal, who were part of a group of teachers who attended an in-service course. The course was designed to help develop statistical knowledge and skills of mathematics teachers particularly from schools with a poor overall performance in mathematics (North, Gal, \& Zewotir, 2014; North \& Scheiber, 2008). A questionnaire based on an existing instrument developed by Beswick et al. (2012) was used to probe various aspects of teachers' knowledge, beliefs and confidence related to the teaching and learning of mathematics and statistics. The original questionnaire (Beswick et al., 2012) focused on mathematics which we extended to the teaching of statistics and the use of technology in classrooms.

The questionnaire included several parts such as questions related to teachers' confidence and beliefs, teaching practices (lesson planning, teaching methods and assessments, etc.), predicting learners' responses and the use of technology.

In this article, we focus on the teachers' responses to items regarding the implementation of technology in their instructional practice. Teachers were required to respond to statements on a four-point Likert item scale with categories 1 ('never'), 2 ('rarely'), 3 ('sometimes') and 4 ('often') to indicate how often they integrated technology in teaching mathematics. They were also asked about their access to calculators, computers and the internet and the extent to which these were used for teaching mathematics in their classrooms. Teachers were also asked to rate their level of confidence in teaching mathematics topics using a three-point Likert item scale with categories 1 ('low'), 2 ('moderate') and 3 ('high'). Their beliefs about teaching and learning mathematics were rated using a three-point Likert item scale with categories 1 ('disagree'), 2 ('neutral') and 3 ('agree').

This research was underpinned by the following research questions: (1) To what extent do mathematics teachers incorporate technology into their teaching practices? (2) To what extent are teachers positive about using technology in the teaching of mathematics? (3) Is there any relationship between demographic factors and the use of technology in instructional practices? 


\section{Participants}

Table 1 presents a description of the participants in terms of various demographic factors.

Table 1 shows that the study involved an almost equal number of female and male teachers, with the majority being 40 years or younger. More teachers (60\%) were teaching Grades 10-12 (FET) than those who taught Grades 4-9 (GET), while $60.0 \%$ completed a bachelor's degree and $40.0 \%$ completed postgraduate studies. Only $21.3 \%$ were from quintile 4 or 5 schools. Table 1 further indicates that $68.0 \%$ of the participants have met with a local group of teachers to study and discuss mathematics and statistics teaching on a regular basis as part of their professional learning, and 45.3\% said that they integrate the National Curriculum Statement Grade R-12 in their teaching process.

\section{Data analysis}

The data were analysed using IBM SPSS Statistics 23 version (George \& Mallery, 2016). The package was used to evaluate the connection between the use of technology for educational instruction purposes and teachers' confidence and beliefs. Moreover, it was used to identify the important factors that may influence teachers' ability to use technology.

We used cross tabulation with chi-square test of independence at significance level alpha equal to 0.05, to explore some relationships. The chi-square test is known as a general test designed to evaluate when the difference between observed frequencies and the expected frequencies under a set of theoretical assumptions is statistically significant (Michael, 2001).

This test is a standard statistical procedure to test whether there is evidence of a statistically significant relationship between two categorical variables, as opposed to the two

TABLE 1: Participants by demographic factors.

\begin{tabular}{|c|c|c|}
\hline Factors & Definition (codes) & Frequency $(\%)$ \\
\hline \multirow[t]{2}{*}{ Gender } & Female (0) & $37(49.3)$ \\
\hline & Male (1) & $38(50.3)$ \\
\hline \multirow[t]{2}{*}{ Level of education } & Bachelor's degree (0) & $35(60.0)$ \\
\hline & Postgraduate and above (1) & $40(40.0)$ \\
\hline \multirow[t]{2}{*}{ Age group } & $\leq 40$ years $(0)$ & $44(58.7)$ \\
\hline & $>40$ years $(1)$ & $31(41.3)$ \\
\hline \multirow[t]{4}{*}{ Quintile school } & Q1 (0) & $15(20.0)$ \\
\hline & Q2 (1) & $28(37.4)$ \\
\hline & Q3 (2) & $16(21.3)$ \\
\hline & Q4 and above (3) & $16(21.3)$ \\
\hline \multirow[t]{2}{*}{ Phases } & GET (Grade 4-9) (0) & $30(40.0)$ \\
\hline & FET (Grade 10-12) (1) & $45(60.0)$ \\
\hline \multirow[t]{2}{*}{ Teaching experience } & $\leq 10$ years $(0)$ & $45(60.0)$ \\
\hline & $>10$ years $(1)$ & $30(40.0)$ \\
\hline \multirow[t]{2}{*}{ Attended mathematics workshop } & No $(0)$ & $30(40.0)$ \\
\hline & Yes (1) & $45(60.0)$ \\
\hline \multirow{2}{*}{$\begin{array}{l}\text { Met with a local group of teachers to } \\
\text { study and discuss mathematics and } \\
\text { statistics teaching on a regular basis }\end{array}$} & No $(0)$ & $24(32.0)$ \\
\hline & Yes (1) & $51(68.0)$ \\
\hline \multirow{2}{*}{$\begin{array}{l}\text { Use National Curriculum Statement in } \\
\text { teaching mathematics and statistics }\end{array}$} & No $(0)$ & $34(45.3)$ \\
\hline & Yes (1) & 41 (54.7) \\
\hline
\end{tabular}

categorical variables operating independently. It is assumed that if the $p$-value is less than 0.05 , we conclude that a significant difference does exist. This test was accordingly used to determine whether there is a statistical significant relationship between teachers' use of technology (using technology in class or consulting the internet for educational instructions) and teachers' confidence (including beliefs). Effectively then, we were exploring whether using internet or technology in the classroom for educational instructions was a reliable relationship with the level of confidence in their ability to teach a variety of mathematics and statistics topics and positive beliefs about teaching in teaching mathematics and statistics.

We further used a comparison of means (a standard test used to compare differences between means of two or more groups) to explore whether there appears to be a statistically significant relationship between teachers' demographics and their use of technology in the different instructional practices. This test was used to examine the magnitude of the difference between two groups in terms of using technology.

Effect size reported in the output of the comparison of means is a name given to a family of indices that measure the magnitude of a treatment. It can help to see how much of a practical significance any result has (Becker, 2000; Cohen, 1988; Kotrlik \& Williams, 2003). Hence, it was used to examine the magnitude of the difference between two groups in terms of using technology. Most of the effect sizes are less than 0.3; this indicates that the difference between groups of demographic factors in terms of using technology in teaching practice is small. Differences observed will thus be deemed to be significant if the $p$-value is less than 0.05 and the effect size is bigger than 0.3. Mean plots are used to see if the mean varies between different groups of the data. They were further used to explore the factors that may influence teachers to integrate technology in their teaching practice.

\section{Ethical considerations}

All ethical considerations stipulated by the University of KwaZulu-Natal were adhered to. Out of the group of 136 teachers who were approached to take part in the study, only 75 opted to participate. The participants were guaranteed anonymity and were also given the choice to withdraw from the research if they wanted to. Permission to carry out the research was granted by University of KwaZulu-Natal with the protocol number HSS/1529/015D.

\section{Findings}

We start by exploring the extent to which the teachers have access to calculators, computers and the internet in teaching mathematics, followed by details about the instructional purposes for which the technology is used. Thereafter we report in more detail on the differences in confidence and beliefs of teachers who use the internet for instructional purposes, and those who do not. This section is organised according to the research questions of the study. 


\section{Research question 1: To what extent do mathematics teachers use technology in their teaching practices?}

\section{Access to technology}

Table 2 displays the results regarding the use of calculators and computers. Of the 75 teachers who were surveyed, only $49(65 \%)$ teachers reported that in the schools where they were teaching calculators were used to teach and learn mathematics and statistics, even though calculators were commonly available. When asked about access to computers, there were even fewer teachers who enjoyed this privilege. There were only $33(44 \%)$ teachers who reported that computers were available in the schools where they teach; only $21(28 \%)$ said that computers were used to teach mathematics and statistics at the schools. Twenty (26.7\%) had access to the internet and $19(25.3 \%)$ said that internet was used for educational instruction.

Reports about the availability of computers at schools suggest similar figures to those reported by the teachers in this study. In 2015 , it was found that $33.2 \%$ of schools had computers (South Africa Institute of Race Relations, 2015). Even though, in the current study, the availability of computers in schools was reported at approximatively $44 \%$, only $28.5 \%$ of the teachers reported that these were used for teaching mathematics and statistics, which represents a limited use of technology.

The use of computers and calculators in teaching mathematics and statistics was disaggregated by the grade in which teachers were teaching. Table 3 indicates that $84.4 \%$ of the teachers who were teaching Grades 10-12 mostly used calculators to teach mathematics, compared to $36.7 \%$ of teachers for Grades 4-9. On the other hand, only $40.0 \%$ of teachers who were teaching in Grades 10-12 reported that they used computers in mathematics and statistics teaching and learning, whereas only $10.0 \%$ of teachers in Grades 4-9 reported that they used computers in the classroom.

It is evident that in the schools represented in the study, the use of computers in the classroom is still at very low

TABLE 2: Access to technology.

\begin{tabular}{|c|c|c|}
\hline \multirow[t]{2}{*}{ Question } & No & Yes \\
\hline & Frequency (\%) & Frequency (\%) \\
\hline Are calculators available in your school? & $26(34.7)$ & $49(65.3)$ \\
\hline $\begin{array}{l}\text { Do you use calculators for teaching } \\
\text { mathematics or statistics }\end{array}$ & $26(34.7)$ & $49(65.3)$ \\
\hline Are computers available? & $42(56.0)$ & $33(44.0)$ \\
\hline $\begin{array}{l}\text { Do you use them for teaching mathematics and } \\
\text { statistics }\end{array}$ & $54(72.0)$ & $21(28.0)$ \\
\hline $\begin{array}{l}\text { Do any of the computers learners use have } \\
\text { access to the internet? }\end{array}$ & $55(73.3)$ & $20(26.7)$ \\
\hline $\begin{array}{l}\text { Do you use the internet for educational } \\
\text { instructional purposes? }\end{array}$ & $56(74.7)$ & $19(25.3)$ \\
\hline
\end{tabular}

TABLE 3: The use of calculators and computers by grade.

\begin{tabular}{lccccc}
\hline \multirow{2}{*}{ Grades } & \multicolumn{2}{c}{ Calculators } & & \multicolumn{2}{c}{ Computers } \\
\cline { 2 - 3 } \cline { 6 - 6 } & Yes (\%) & No (\%) & & Yes (\%) & No (\%) \\
\hline $4-9$ & $11(36.7)$ & $19(63.3)$ & & $3(10.0)$ & $27(90.0)$ \\
$10-12$ & $38(84.4)$ & $7(15.6)$ & & $18(40.0)$ & $27(60.0)$ \\
\hline
\end{tabular}

levels and much effort is needed to sensitise teachers to using computers for improved teaching of mathematics and statistics. This finding shows that the DOE (2007) recommendation that the use of ICT in the classroom should aim to develop a range of skills ranging from basic ICT skills to developing specialisation and innovation in ICT education is unlikely to be met under these conditions. It is clear that teachers would need much assistance and continuous professional teacher development on the implementation of information technology pedagogical knowledge in relation to integrating ICT in the teaching of mathematics (Cassim, 2010). Given that more than half the teachers do not have computers available at their schools, it is unrealistic to expect that these teachers would be able to take on the vision of the DOE in using ICT to improve the learning outcomes in the education system (DOE, 2007).

\section{The instructional purposes for which the technology is used}

Mishra and Koehler (2006) agree that the connection between technology and teaching can transform the conceptualisation and the practice of teacher education, teacher training and teachers' professional development. Teachers can use technology in different ways, such as in simple drill and practice tasks.

Drill and practice mathematics software offers teachers a relatively simple way to use technology in the classroom (Kuiper \& De Pater-Sneep, 2014). Teachers could also use technology in more complex tasks such as using simulations in investigating real-life data. Table 4 indicates how often technology (computers) is implemented in different teaching practices. It can be noted from Table 3 that most teachers reported that they never used technology for any of the instructional activities mentioned. It is clear that most of the teachers in the study group were not using technology at all, not even in the most rudimentary way. Activities such as collecting and retrieving data from computers are associated with exploring data in real-life applications. The use of statistics in understanding and making informed decisions in real life is an important outcome of the subject, and these findings show that teachers need more help in this regard.

\section{The use of the internet and teachers' confidence and beliefs}

The data allowed us to look in more detail at the specific use of the internet for instructional purposes and to test whether this use was linked to certain factors. Ndlovu and Lawrence's

TABLE 4: Exploration of the use of technology in teachers' practice.

\begin{tabular}{|c|c|c|c|c|}
\hline Teaching practice & Never & Rarely & Sometimes & Often \\
\hline Drill and practice & $46(61.3)$ & $7(9.3)$ & $12(16.0)$ & $10(13.4)$ \\
\hline Demonstrate statistics principles & $42(56.0)$ & $9(12.0)$ & $9(12.0)$ & $15(20.0)$ \\
\hline $\begin{array}{l}\text { Collect data using sensors or probes } \\
\text { (collecting data using software) }\end{array}$ & $48(64.0)$ & $13(17.3)$ & $6(8.0)$ & $8(11.7)$ \\
\hline Retrieve or exchange data & $47(62.7)$ & $8(10.7)$ & $12(16.0)$ & $8(10.7)$ \\
\hline Solve and compute statistical problems & $46(61.3)$ & $8(10.7)$ & $10(13.3)$ & $11(14.7)$ \\
\hline Take a test or quiz & $41(54.7)$ & $8(10.7)$ & $11(14.7)$ & $15(20.0)$ \\
\hline
\end{tabular}

Note: Data are shown as frequency with percentage in brackets. 
(2012) view is that access to ICT enables quality use for educational purposes. It is expected that a teacher who makes use of the internet as an additional teaching tool will most likely earn their students' respect and regard, which in turn may motivate teachers to develop more innovative indeas about teaching. Some studies contend that teachers with more access to the Web for instructional purposes had higher levels of self-determination and that teachers with better computer access had lower computer nervousness and more computer self-efficacy (Liu \& Kleinsasser, 2015). Thus, access to technology may be a factor that builds up teachers' knowledge.

We now investigate the links between the use of the internet and teachers' confidence and beliefs.

\section{Teachers' confidence in teaching mathematics}

Recent studies articulate that there exists a connection between teachers' confidence and the use of technology (Brändström, 2011; O’Dwyer et al., 2003; Sabzian \& Gilakjani, 2013). Sabzian and Gilakjani (2013) argue that the lack of computer instruction often accounts for teachers' low confidence levels when they initiate computer activities. In this study, we explored whether teachers who use the internet for educational instruction purposes are confident in their ability to teach mathematics. We considered topics such as percentage, fraction, decimal, inference and prediction, measurement, pattern and algebra, mental computation, pie graphs and histograms, range and variations, ideas of sampling and data collection, and so on.

The results showed a statistical significant relationship between using the internet for educational instructional purposes and teachers' confidence in teaching mathematics or statistics topics. It can be noted from Table 5 that teachers who use the internet for instructional purposes expressed a high confidence in teaching percentages $\left(\chi^{2}=6.082(2)\right.$, effect size $=0.285, p$-value $=0.048)$, ratios and proportions $\left(\chi^{2}=9.835(2)\right.$, effect size $=0.362, p$-value $\left.=0.007\right)$, pie charts and histograms $\left(\chi^{2}=12.231(2)\right.$, effect size $=0.320$, $p$-value $=0.048)$, pattern and algebra $\left(\chi^{2}=13.747(2)\right.$, effect size $=0.428, p$-value $=0.001)$, measurement $\left(\chi^{2}=6.399(2)\right.$, effect size $=0.292, p$-value $=0.041)$ and mental computation $\left(\chi^{2}=8.573(2)\right.$, effect size $=0.338, p$-value $\left.=0.014\right)$.

The values of effect sizes in Table 5, Table 6 and Table 7 ranged between 0.2 and under 0.4 which indicate moderate practical significance (Becker, 2000; Cohen, 1988; Kotrlik \& Williams, 2003).

\section{Teachers' beliefs about the goals of teaching mathematics}

We further examined whether there is a significant relationship between using the internet for educational instructional purposes and teachers' beliefs about the nature of mathematics. It can be noted from Table 6 that teachers who reported that they use the internet were more likely to agree about some broad goals of teaching mathematics (as identified by Beswick et al., 2012) than those who did not. Teachers who reported that they use the internet agreed that mathematics teaching should assist learners to develop an attitude of inquiry (asking questions, being curious about solutions $)\left(\chi^{2}=6.362(2)\right.$, effect size $=0.291, p$-value $\left.=0.042\right)$, statistics teaching should assist learners to develop a positive attitude to problem-solving $\left(\chi^{2}=6.050(2)\right.$, effect size $=0.284$, $p$-value $=0.049$ ), and statistical literacy, thinking and reasoning are the main goals in statistical teaching and learning $\left(\chi^{2}=7.458(2)\right.$, effect size $=0.315$, $p$-value $\left.=0.024\right)$. The findings from Table 5 further show that the use of the internet for educational instructional purposes is associated with a stronger belief in the value of linking teaching to other key areas $\left(\chi^{2}=11.797(2)\right.$, effect size $=0.404, p$-value $\left.=0.003\right)$ as well as the need for applying statistics in real-life settings outside of the classroom situation $\left(\chi^{2}=8.701\right.$ (2), effect size $=0.397, p$-value $=0.013$.

TABLE 5: Using internet for instructional purposes and teachers' confidence.

\begin{tabular}{|c|c|c|c|c|c|c|c|}
\hline \multirow[t]{2}{*}{ Topics } & \multirow{2}{*}{$\begin{array}{l}\text { Teachers' } \\
\text { confidence }\end{array}$} & \multicolumn{6}{|c|}{ Using internet for instructional purposes } \\
\hline & & No & Yes & Total & $\chi^{2}(d f)$ & $p$ value & Effect size \\
\hline \multirow[t]{3}{*}{ Percentages } & Low & $7(12.5)$ & $1(5.3)$ & $8(10.7)$ & $6.082(2)$ & 0.048 & 0.285 \\
\hline & Moderate & $16(28.6)$ & $1(5.3)$ & $17(22.7)$ & - & - & - \\
\hline & High & $33(58.9)$ & $17(89.5)$ & $50(66.7)$ & - & - & - \\
\hline \multirow[t]{3}{*}{ Ratios and proportions } & Low & $11(19.6)$ & $0(0.0)$ & $11(14.7)$ & $9.835(2)$ & 0.007 & 0.362 \\
\hline & Moderate & $23(41.1)$ & $4(21.1)$ & $27(36.0)$ & - & - & - \\
\hline & High & $22(39.3)$ & $15(78.9)$ & $37(49.3)$ & - & - & - \\
\hline \multirow[t]{3}{*}{ Pie graphs and histograms } & Low & $11(19.6)$ & $1(5.3)$ & $12(16.0)$ & $12.231(2)$ & 0.002 & 0.320 \\
\hline & Moderate & $17(30.4)$ & $0(0.0)$ & $17(22.7)$ & - & - & - \\
\hline & High & $28(50.0)$ & $18(94.7)$ & $46(61.3)$ & - & - & - \\
\hline \multirow[t]{3}{*}{ Pattern and algebra } & Low & $11(19.6)$ & $0(0.0)$ & $11(14.7)$ & $13.747(2)$ & 0.001 & 0.428 \\
\hline & Moderate & $19(33.9)$ & $1(5.3)$ & $20(26.7)$ & - & - & - \\
\hline & High & $26(46.4)$ & $18(94.7)$ & $44(58.7)$ & - & - & - \\
\hline \multirow{2}{*}{$\begin{array}{l}\text { Measurement (Length, } \\
\text { area, volume and time) }\end{array}$} & Low & $9(16.1)$ & $0(0.0)$ & $9(12.0)$ & $6.399(2)$ & 0.041 & 0.292 \\
\hline & High & $27(48.2)$ & $15(78.9)$ & $42(56.0)$ & - & - & - \\
\hline \multirow[t]{3}{*}{ Mental computation } & Low & $14(25.0)$ & $2(10.5)$ & $16(21.3)$ & $8.573(2)$ & 0.014 & 0.338 \\
\hline & Moderate & $25(44.6)$ & $4(21.1)$ & $29(38.7)$ & - & - & - \\
\hline & High & $17(30.4)$ & $13(68.4)$ & $30(40.0)$ & - & - & - \\
\hline
\end{tabular}

Note: Yes, No and Total columns are shown as frequency with percentage in brackets. 
TABLE 6: Using internet for education instructional purpose and teachers' beliefs about teaching mathematics.

\begin{tabular}{|c|c|c|c|c|c|c|c|}
\hline \multirow[t]{2}{*}{ Variable } & \multirow{2}{*}{$\begin{array}{l}\text { Level of } \\
\text { agreement }\end{array}$} & \multicolumn{6}{|c|}{ Using internet for educational instructional purpose } \\
\hline & & No & Yes & Total & $\chi^{2}(d f)$ & $p$ value & Effect size \\
\hline \multicolumn{8}{|l|}{ Teachers' beliefs about goals } \\
\hline \multirow{3}{*}{$\begin{array}{l}\text { Mathematics teaching should assist } \\
\text { learners to develop an attitude of } \\
\text { inquiry (asking questions, being } \\
\text { curious about solutions) }\end{array}$} & Disagree & $1(1.8)$ & $0(0.0)$ & $1(1.3)$ & $6.362(2)$ & 0.042 & 0.291 \\
\hline & Neutral & $14(25.0)$ & $00.0)$ & $14(18.7)$ & - & - & - \\
\hline & Agree & $41(73.2)$ & $19(100.0)$ & $60(80.0)$ & - & - & - \\
\hline \multirow{3}{*}{$\begin{array}{l}\text { Statistical literacy, thinking and } \\
\text { reasoning are the main goals in } \\
\text { statistical teaching and learning }\end{array}$} & Disagree & $1(1.8)$ & $0(0.0)$ & $1(1.3)$ & $7.458(2)$ & 0.024 & 0.315 \\
\hline & Neutral & $16(28.6)$ & $0(0.0)$ & $16(21.3)$ & - & - & - \\
\hline & Agree & $39(69.6)$ & $19(100.0)$ & $58(77.3)$ & - & - & - \\
\hline \multicolumn{8}{|l|}{ Goals of mathematics } \\
\hline \multirow{3}{*}{$\begin{array}{l}\text { Connecting mathematics to other } \\
\text { key learning areas }\end{array}$} & Low & $20(35.7)$ & $1(5.3)$ & $21(28.0)$ & $11.79(2)$ & 0.003 & 0.404 \\
\hline & Moderate & $21(37.5)$ & $5(26.3)$ & $26(34.7)$ & - & - & - \\
\hline & High & $15(26.8)$ & $13(68.4)$ & $28(37.3)$ & - & - & - \\
\hline \multirow{2}{*}{$\begin{array}{l}\text { Using statistics outside of the } \\
\text { classroom }\end{array}$} & Low & $17(30.4)$ & $2(10.5)$ & $19(25.3)$ & $8.701(2)$ & 0.013 & 0.397 \\
\hline & Moderate & $22(39.3)$ & $4(21.1)$ & $26(34.7)$ & - & - & - \\
\hline
\end{tabular}

Note: Yes, No and Total columns are shown as frequency with percentage in brackets.

TABLE 7: Teachers' beliefs about using technology in teaching and learning.

\begin{tabular}{lrccc}
\hline Teachers' beliefs & Disagree & Neutral & Agree & Total \\
\hline $\begin{array}{l}\text { Using technology to assess } \\
\text { mathematics learning }\end{array}$ & $3(4.0)$ & $12(16)$ & $60(80.0)$ & $75(100)$ \\
$\begin{array}{l}\text { Using technology helps with } \\
\text { increasing learners' learning and } \\
\text { understanding of statistics }\end{array}$ & $11(14.7)$ & $15(20)$ & $49(65.3)$ & $75(100)$ \\
\hline
\end{tabular}

Note: Data are shown as frequency with percentage in brackets.

\section{Research question 2: To what extent are teachers positive about using technology in the teaching of mathematics?}

Table 7 indicates that $60(80 \%)$ of the 75 teachers in the study had a positive view regarding the use of technology to facilitate teaching and learning mathematics and statistics topics and $49(65.3 \%)$ expressed a positive belief that it improves learners' understanding.

We further used a comparison of means to identify factors that may be associated with teachers' positive beliefs towards technology. It can be noted from Table 8 that teachers younger than 40 were more confident about the potential of technology to influence learning and understanding of statistics positively than was the case for teachers who were older than $40(F=4.912, p$-value $=0.030$, effect size $=0.251)$. They further believed that using technology helps to increase learners' learning and understanding of statistics $(F=8.886$, $p$-value $=0.004$, effect size $=0.329)$. Younger teachers were thus more positive about the use of technology to enhance understanding of statistics than older teachers. These young teachers are the same group that have 10 or fewer years of teaching experience and it will be shown that they are the group who are more likely to make use of technology in the classroom.

These results support the findings of Cavas et al. (2009), who reflected on science teachers' attitudes towards the use of technology in education. They found that the attitudes of young science teachers in their study (age group 20-35) were more positive about using technology in the classroom, which was significantly different from teachers in other age groups (36-49 and 50+). However, in another study,
Choi (1992) found that older teachers displayed more positive attitudes towards computer use in education than was the case for the younger teachers in that study.

We further note that teachers who use the National Curriculum Statement in their teaching have positive beliefs that technology influences learning and understanding of statistics $40(F=7.164, p$-value $=0.009$, effect size $=0.299)$ and that using technology helps to increase learners' learning and understanding of statistics $(F=4.995, p$-value $=0.028$, effect size $=0.253$ ). This indicates the importance of consulting the curriculum as the factor that encourages teachers to use technology in their teaching process.

Teachers largely agreed that the use of technology helps learners to develop their understanding of mathematics and statistics topics. Forty-nine out of $75(65.3 \%)$ teachers said they believed that they would integrate technology into teaching and learning mathematics and statistics in the classroom.

Furthermore, the findings indicate that teachers who reported that they meet with a local group of teachers and discuss mathematics and statistics teaching on a regular basis as a part of their professional learning expressed positive beliefs that technology enhances learners' understanding $(F=10.541$, $p$-value $=0.002$, effect size $=0.355)$ and that using technology helps to increase learners' learning and understanding of statistics $(F=4.328, p$-value $=0.041$, effect size $=0.237)$. This finding indicates that in professional learning, teachers continue to acquire new skills while collaborating with other teachers and can share the best practice and integrate the innovations in the classroom. The DOE (2007) supports this idea that teachers' desires and benefits should be the driving force for their professional growth.

\section{Research question 3: Is there any relationship between demographic factors and the use of technology in instructional practices?}

Technology knowledge, as with other aspects of teacher knowledge, is not constant. It develops over time according to teachers' professional development or training, teaching 
TABLE 8: Teachers' beliefs about technology and effect of demographic factors.

\begin{tabular}{|c|c|c|c|c|c|c|}
\hline Teachers' beliefs about technology & Factors & Sum of squares & Mean square & $F$ & $p$ value & Effect size \\
\hline \multirow{3}{*}{$\begin{array}{l}\text { Using technology to assess } \\
\text { mathematics learning. }\end{array}$} & Age group & 2.569 & 2.569 & 4.912 & 0.030 & 0.251 \\
\hline & Using curriculum & 3.641 & 3.641 & 7.164 & 0.009 & 0.299 \\
\hline & Professional learning & 5.141 & 5.141 & 10.541 & 0.002 & 0.355 \\
\hline \multirow{3}{*}{$\begin{array}{l}\text { Using technology helps with } \\
\text { increasing learners' learning } \\
\text { and understanding of statistics. }\end{array}$} & Age group & 2.136 & 2.136 & 8.886 & 0.004 & 0.329 \\
\hline & Using curriculum & 1.260 & 1.260 & 4.995 & 0.028 & 0.253 \\
\hline & Professional learning & 1.102 & 1.102 & 4.328 & 0.041 & 0.237 \\
\hline
\end{tabular}

TABLE 9: Factors associated with teachers' use of technology.

\begin{tabular}{|c|c|c|c|c|c|}
\hline Factor & Teachers' practice & Mean square & $F$ & $p$ value & Effect size \\
\hline \multirow[t]{6}{*}{ Level of education } & Drill and practice & 29.501 & 32.686 & 0.000 & 0.309 \\
\hline & Demonstrate statistics principles & 43.819 & 47.700 & 0.000 & 0.395 \\
\hline & Collect data using sensors or probes & 19.069 & 24.034 & 0.000 & 0.248 \\
\hline & Retrieve or exchange data & 26.244 & 31.960 & 0.000 & 0.304 \\
\hline & Solve and compute statistical problems & 34.744 & 40.488 & 0.000 & 0.357 \\
\hline & Take a test or quiz & 45.054 & 49.128 & 0.000 & 0.402 \\
\hline \multirow[t]{5}{*}{ Quintile schools } & Drill and practice & 4.536 & 3.938 & 0.012 & 0.143 \\
\hline & Demonstrate statistics principles & 8.384 & 6.944 & 0.000 & 0.227 \\
\hline & Collect data using sensors or probes & 6.383 & 6.761 & 0.000 & 0.222 \\
\hline & Retrieve or exchange data & 8.575 & 8.496 & 0.000 & 0.264 \\
\hline & Solve and compute statistical problems & 3.681 & 2.588 & 0.060 & 0.099 \\
\hline \multirow[t]{5}{*}{ Gender } & Drill and practice & 15.586 & 14.258 & 0.000 & 0.163 \\
\hline & Demonstrate statistics principles & 22.461 & 18.544 & 0.000 & 0.203 \\
\hline & Collect data using sensors or probes & 12.281 & 13.855 & 0.000 & 0.160 \\
\hline & Solve and compute statistical problems & 15.586 & 13.909 & 0.000 & 0.160 \\
\hline & Take a test or quiz & 25.818 & 21.869 & 0.000 & 0.231 \\
\hline \multirow[t]{6}{*}{ Experience } & Drill and practice & 20.909 & 20.494 & 0.000 & 0.219 \\
\hline & Demonstrate statistics principles & 21.780 & 17.844 & 0.000 & 0.196 \\
\hline & Collect data using sensors or probes & 10.276 & 11.244 & 0.001 & 0.133 \\
\hline & Retrieve or exchange data & 16.820 & 17.701 & 0.000 & 0.195 \\
\hline & Solve and compute statistical problems & 13.176 & 11.421 & 0.001 & 0.135 \\
\hline & Take a test or quiz & 12.500 & 9.171 & 0.003 & 0.112 \\
\hline \multirow[t]{6}{*}{ Attended workshops } & Drill and practice & 7.738 & 6.445 & 0.013 & 0.081 \\
\hline & Demonstrate statistics principles & 9.572 & 6.897 & 0.011 & 0.086 \\
\hline & Collect data using sensors or probes & 4.485 & 4.516 & 0.037 & 0.058 \\
\hline & Retrieve or exchange data & 7.848 & 7.313 & 0.009 & 0.091 \\
\hline & Solve and compute statistical problems & 7.738 & 6.301 & 0.014 & 0.079 \\
\hline & Take a test or quiz & 7.114 & 4.951 & 0.029 & 0.064 \\
\hline
\end{tabular}

Note: Effect sizes between 0.2 and 0.4 (in bold) indicate that the difference between groups in terms of using technology has moderate practical significance.

experience as well as teachers' attainment of a higher level of education, and so on. The comparison of means (a standard test used to compare differences between means of two or more groups) was used to identify factors associated with teachers' tendency to integrate technology into their teaching practice as reported in Table 4 . The teachers' demographic factors that were tested included school quintile, gender, age, teaching experiences, education level, workshop attendance, grades taught, level of education and instruction practices. The analysis reported in Table 9 was made by comparing the means at a significance level (alpha) equal to 0.05 , between the variables that were explained in Table 4 and the demographic factors reported in Table 1.

The findings reveal that the difference between the means is statistically significant for the factors of gender, level of study, teaching experience, attending workshops and school quintile and their ability to integrate technology in different instructional practices at alpha equal to 0.05. Table 9 reports only significant effect $p$-values less than 0.05 . It can also be noted from Table 9 that the effect sizes between 0.2 and 0.4 (in bold) indicate that the difference between groups in terms of using technology has moderate practical significance. On the other hand, it can be noted from Table 8 that the effect sizes less than 0.2 indicate that the difference between groups in terms of using technology has moderate practical significance (Kotrlik \& Williams, 2003).

We also discuss the statistical relationship between some factors and the use of technology reported in Table 9 by examining which demographic group may be more likely to use technology in instructional practice than other groups. Regression analysis was made using mean plots to compare the magnitude of each group in terms of using technology; however, only those that reflected a moderate difference are reported.

We found that teachers who took postgraduate courses may be more likely to use technology than teachers who have a bachelor's degree or below. It can be noted from Figure 1 that 
means scores for teachers who attended postgraduate courses are greater in terms of taking a test or quiz, retrieving and exchanging data and demonstrating statistical principles than those with bachelor's degrees in terms of using technology (e.g. 2.230 versus 1.340 and 2.350 versus 1.510 ). This result was similar to findings in a previous study that education level contributes to teachers' use of technology in instructional practices (Mathews \& Guarino, 2000).

The education department introduced a funding policy by using a system of categorising schools into five quintiles in order to inform decisions around financial allocations. Quintile 1 schools are those serving the poorest children while Quintile 5 schools cater for children who come from well-resourced backgrounds. Looking at Table 9, there also appears to be a statistically significant difference between teachers' school quintile and their ability to integrate technology in different instructional practices.

We observe from Figure 2 that teachers who teach in quintile 4 or 5 schools are more likely to use technology in instructional practices than teachers from the quintile 1-3 schools. A general trend in the use of technology as the quintile ranking of the school increased can be noted from Figure 3: as the quintile ranking of the school increases, the use of technology in the various instructional activities at that school increases.

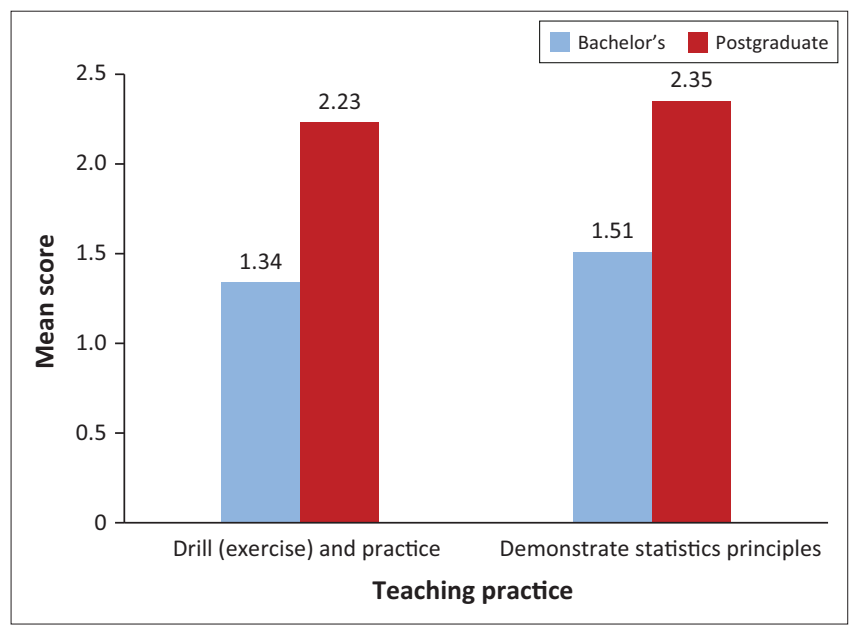

FIGURE 1: Using technology for instructional practice by level of education.

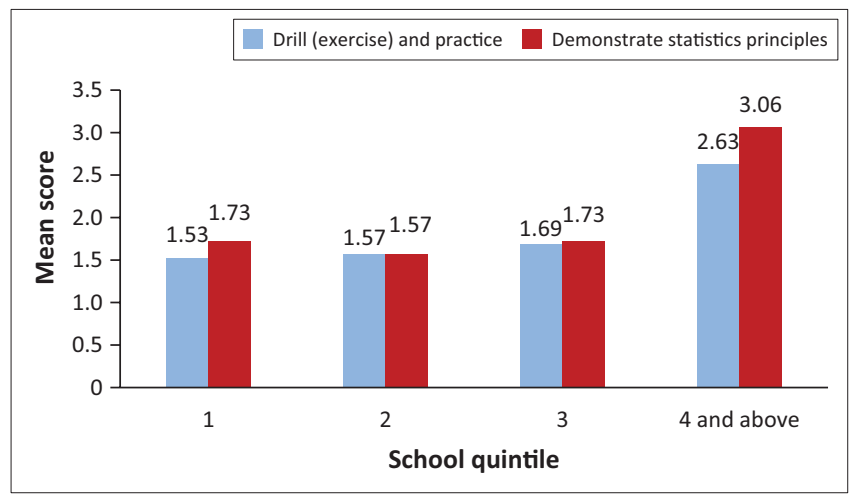

FIGURE 2: Using technology for instructional practice by school quintile.
Thus, mean scores for teachers who teach in quintile 4 and 5 are greater in terms of drilling and practice and demonstrating statistical principles than for those who teach in quintile 1, 2 and 3 schools in terms of using technology (e.g. 2.630 versus 1.690 or $1.570,3.060$ versus 1.750 or 1.570$)$.

It is evident, therefore, that teachers who teach in the poorest schools are using technology to a lesser extent than those in the more well-resourced schools, which illustrates the digital divide between the poorest and the richest schools. However, it is important to note that teachers need more than access to use technology; they also need support in using the technology to teach more effectively. Ndlovu and Lawrence (2012) point out that it is not simply the availability of technology that brings about improvements in learning, but the ways in which this technology is used. Many studies have also reported that poorly resourced schools have less access to ICT facilities than well-resourced schools (Ndlovu \& Lawrence, 2012), and the results of the current study also support such findings.

The findings further showed that male teachers are more likely to integrate technology into their educational practice than female teachers, given that the mean scores of male teachers were higher than those of female teachers (e.g. 2.500 versus $1.405,0.921$ versus 0.165 , etc.). This finding supports results from a study in Africa (Buabeng-Andoh, 2012, p. 39), which explored factors that influence 'teachers' adoption and integration of information and communication technology'. His finding also showed that there was a significant difference between Ghanaian male and female teachers in technical ICT capabilities, where he found evidence that male teachers' scores were higher than those of female teachers in relation to the use of ICT in the classroom for instructional purposes.

Furthermore, it was noted that teachers whose teaching experience is 10 years or fewer were more likely to use technology than the teachers with teaching experience more than 10 years (e.g. 2.180 versus 1.250, 2.330 versus 1.400 , etc.). This finding was also reported in another study (Almekhlafi \& Almeqdadi, 2010), that is, that novice teachers are more likely to use technology and the internet in several teaching practices, which may be because they grew up in the technological era.

A statistically significant difference was also apparent between using technology in instructional practice and professional learning. This means that teachers who attended mathematical workshops may be more likely to use technology than those who did not (e.g. 2.148 versus 1.357, 1.967 versus 1.143 , etc.). However, the effect sizes (Table 9) are small for all instructional practice. This means that the difference in terms of using technology between those who attended workshops and those who did not is small in practice. However, it appeared that the effect sizes (Table 9) are small for all instructional practice. This means that the difference in terms of using technology between those who attended workshops and 
those who did not is small in practice. Mueller et al. (2008) found that attending professional development workshops influences teachers' use of technology. Perhaps workshops that focus on the use and application of technology in the teaching of mathematics specifically may prove to have a bigger influence on whether teachers opt to use technology or not. Mueller et al. (2008) noted that 'professional development' and the 'continuing support of good practice' play a valuable role in sustaining the use of ICT in the classroom.

\section{Conclusion}

Digital classrooms to support students' learning have been the focus of research recently and this article reveals some of the challenges that schools in poorer communities in South Africa experience in this regard. Results from this study indicate that approximately a quarter of teachers have access to ICT for teaching mathematics. The use of ICT is even lower in the earlier grades (4-9), where only $10 \%$ of the teachers said they used ICT for teaching mathematics. Furthermore, the data showed that teachers are generally more comfortable with integrating calculators when teaching mathematics and statistics, as compared to using computers. This indicates that teachers may need training in the integration of computers into the teaching of mathematics and statistics in the classroom. Even though the practice of integrating technology into teaching instruction was not well developed among these teachers, they exhibited a positive view with respect to teaching using technology. Of interest is the finding that teachers who reported that they use the internet for instructional purposes held more positive views about the broad goals of mathematics and were also more confident about teaching mathematics than those teachers who did not. Beswick et al. (2012) assert that it is teachers' beliefs about general principles about the learning and teaching of mathematics that make a difference to student learning. This study suggests that teachers who have access to internet resources have progressive views about what the goals of mathematics and statistics should be. They also have stronger beliefs about the role of real-life applications in learning statistics and the need for connections across various subjects. The study also found that teachers who use the internet have higher levels of confidence in teaching mathematics. This may be because teachers who have access to a wider set of resources have a greater chance of learning more about the broad goals and applicability of mathematics beyond the confines of the classroom. Knowing more about the connections between mathematics and the real world helps people to better understand the role of fundamental concepts such as percentages, and this may in turn improve their confidence about teaching these concepts.

A problem that has been exposed is that although some schools are reported to have computers, these computers are not used in instructional practice, but are used for administrative purposes. It is not clear whether this is because teachers do not have the necessary skills or are reluctant to use the computers, or whether it is because school management is restricting the teachers' access to the technology. If computers are available but are not being used, the possible reasons for this state of affairs need to be urgently probed. Interventions that seek to increase access to technology will not be successful if the roll-out of computers does not result in a concomitant increase in the teachers' use of the technology. This study has provided evidence that teachers who attend workshops are more likely to use technology in their instructional practices than those who do not; hence, interventions that aim to increase the use of ICT in schools must be accompanied by continuous support. It is the support through workshops that will enable teachers to develop confidence in using technology and this may lead to more progressive attitudes by school management regarding the use of computers in classrooms. An important finding of the study is that teachers display different levels of technological readiness and enthusiasm according to their age, experience, gender and how well resourced their school is. Older teachers appear to need more support to help them become more confident to take on the technology.

Younger teachers are more confident and will not need as much support as their older counterparts. In addition, the study has also provided further evidence of the digital divide between schools with different quintile rankings. The digital divide presents a barrier to achieving equity in the provision of quality education to all learners. The removal of the digital divide requires more than just resources because it is the way in which the resources are used that makes the difference in the quality of the learning experience that is offered. The study shows that teachers from quintile 1 schools need much more sustained attention and support, different in form and substance from those from quintile 4 and above.

Successful integration of technology can have a transformative effect on schools and the education system as a whole. The study shows that teachers who have made a start at using the internet for their teaching have also developed broader understandings about the value and aim of teaching mathematics. Hence, helping teachers to take on technological resources is likely to assist them to develop new pedagogies that can help learners engage productively with the content of the subject. Continuous professional development will be required to help teachers integrate the newly acquired technological knowledge into their pedagogical knowledge so that they can develop in all the components specified in Mishra and Koehler's (2006) TPACK framework. In order for the DOE to realise their vision of helping their learners to function effectively in a knowledge society by using appropriate ICT in their schools (DOE, 2007), teachers need sustained support and assistance to develop the necessary ICT capabilities. Any intervention that involves provision of technological resources such as internet access, mobile tablets or laptops will need to be accompanied by the relevant teacher professional development training courses, as well as training and sustained support for using and maintaining the infrastructure. 


\section{Acknowledgements Competing interests}

The authors declare that they have no financial or personal relationships that may have inappropriately influenced them in writing this article.

\section{Authors' contributions}

O.U. performed the analysis of data and made a first draft of the manuscript. S.B. refined the draft. D.N. was responsible for checking the accuracy and suitability of the statistical analysis. O.U., S.B. and D.N. contributed to the conception of the study.

\section{References}

Albion, P.R., Jamieson-Proctor, R., \& Finger, G. (2011). Age-related differences in ICT access and confidence among pre-service teachers. In Proceedings of the 28th Annual Conference of the Australasian Society for Computers in Learning in Tertiary Education (pp. 21-32), ASCILITE. Retrieved from https://www. learntechlib.org/p/43527

Ali, M. (2015). Using technology in the classroom: A study with Turkish pre-service EFL teachers. The Turkish Online Journal of Educational Technology, 14(2), 229-240. Retrievd from http://www.tojet.net/articles/v14i2/14225.pdf

Almekhlafi, A.G., \& Almeqdadi, F.A. (2010). Teachers' perceptions of technology integration in the United Arab Emirates school classrooms. Journal of Educational Technology \& Society, 13(1), 165-175. Retrieved from https://www.j-ets.net/ETS/ journals/13_1/16.pdf

Bansilal, S. (2015). Exploring student teachers' perceptions of the influence of technology in learning and teaching mathematics. South African Journal of Education, 35(4), 1-8. https://doi.org/10.15700/saje.v35n4a1217

Becker, L.A. (2000). Effect size (ES). Colorado Springs, CO: University of Colorado. Retrieved from https://www.uccs.edu/lbecker/effect-size

Beswick, K. (2007). Teachers' beliefs that matter in secondary mathematics classrooms Educational Studies in Mathematics, 65(1), 95-120. https://doi.org/10.1007/ s10649-006-9035-3

Beswick, K., Callingham, R., \& Watson, J. (2012). The nature and development of middle school mathematics teachers' knowledge. Journal of Mathematics Teacher Education, 15(2), 131-157. https://doi.org/10.1007/s10857-011-9177-9

Brändström, C. (2011). Using the internet in education - Strengths and weaknesses: A qualitative study of teachers' opinions on the use of the internet in planning and instruction. Gävle: University of Gävle. Retrieved from http://www.diva-portal.org/ smash/get/diva2:438827/FULLTEXT01.pdf

Buabeng-Andoh, C. (2012). An exploration of teachers' skills, perceptions and practices of ICT in teaching and learning in the Ghanaian second-cycle schools. practices of ICT in teaching and learning in the Ghanaian second-cycle schools.
Contemporary Educational Technology, 3(1),36-49. Retrieved from https://pdfs. Contemporary Educational Technology, 3(1), 36-49. Retrieved from https://pdf
semanticscholar.org/ca7d/a8aa6839dd2175fcdedf15d04b13504661d9.pdf

Cassim, V. (2010). The pedagogical use of ICTs for teaching and learning within grade eight mathematics in South African schools. Unpublished master's thesis, Northeight mathematics in South African schools. Unpublished master's thesis, Northnet/10394/4487

Cavanagh, R.F., Reynolds, P.S., \& Romanoski, J.T. (2004). Information and communication technology learning in the classroom: The influence of students, the class-group, teachers and the home. In P. Jeffrey (Ed.), Proceedings of the Annual Meeting of the Australian Association for Research in Education (pp 1-20). Melbourne: AARE. Australian Association for Research in Education (pp. 1-20). Melbourne: AARE.
Retrieved from https://www.aare.edu.au/data/publications/2004/cav04445.pdf

Cavas, B., Cavas, P., Karaoglan, B., \& Kisla, T. (2009). A study on science teachers' attitudes toward information and communication technologies in education. The Turkish Online Journal of Educational Technology, 8(2), 20-32. Retrieved from http://www.tojet.net/articles/v8i2/822.pdf

Chance, B., Ben-Zvi, D., Garfield, J., \& Medina, E. (2007). The role of technology in improving student learning of statistics. Technology Innovations in Statistics Education, 1(1). Retrieved from https://escholarship.org/uc/item/8sd2t4r

Choi, Y.K. (1992). Attitudes toward and knowledge of microcomputers used for instruction among commercial high school teachers in Korea. Unpublished doctoral dissertation, University of Georgia, Athens, GA. Retrieved from http:// dl.acm.org/citation.cfm?id=920023

Cohen, J. (1988). Statistical power analysis for the behavioral sciences. Hillsdale, NJ: Lawrence Earlbaum Associates. https://doi.org/10.1002/bs.3830330104

Cox, M.J., Preston, C., \& Cox, K. (1999, September). What factors support or prevent teachers from using ICT in their classrooms? Paper presented at the British Educational Research Association Annual Conference, University of Sussex at Brighton. Retrieved from https://www.leeds.ac.uk/educol/documents/ 00001304.htm

Cubukcuoglu, B. (2013). Factors enabling the use of technology in subject teaching International Journal of Education and Development using Information and Communication Technology, 9(3), 50-60. Retrieved from https://www.learntechlib. $\mathrm{org} / \mathrm{d} / 130273$
Department of Basic Education (2010). Guidelines on e-safety in schools: Educating towards responsible, accountable and ethical use of ICT in education. Pretoria: DBE. Retrieved from https://www.education.gov.za/ArchivedDocuments/Archived Articles/Guidelinesone-SafetyinSchools11-09-17.aspx

Department of Basic Education. (2016). Information guide for 17th annual NTA 2016. Pretoria: DBE. Retrieved from http://www.education. gov.za/LinkClick.aspx?filetic ket=FbCMTbqRPMo\%3D\&tabid=441\& portalid $=0 \&$ mid $=3091$

Department of Education. (2004). White paper on e-education. Notice 1869 of 2004. Government Gazette No.236734 of 26 August 2004. Retrieved from www.sahistory. org.za/sites/default/files/white\%20_paper_on_e-education_2004.pdf

Department of Education. (2007). Guidelines for teacher training and professional development in ICT. Retrieved from http://www.schoolnet.org.za/sharing/ guidelines teacher_training.pdf

Dzansi, D.Y., \& Amedzo, K. (2014). Integrating ICT into rural South African schools: Possible solutions for challenges. International Journal of Educational Sciences, 6(2) 341-348. Retrieved from https://doi.org/10.1080/09751122.2014.11890145

Ernest, P. (1989). The knowledge, beliefs and attitudes of the mathematics teacher: $A$ model. Journal of Education for Teaching, 15(1), 13-33. https://doi.org/10.1080/ 0260747890150102

Forster, P.A. (2006). Assessing technology-based approaches for teaching and learning mathematics. International Journal of Mathematical Education in Science and Technology, 37(2), 145-164. https://doi.org/10.1080/00207390500285826

GAISE College Report ASA Revision Committee. (2016). Guidelines for assessment and instruction in statistical education (GAISE) College Report 2016. American Statistical Association. Retrieved from http://www.amstat.org/asa/files/pdfs/ GAISE/GaiseCollege_Full.pdf

George, D., \& Mallery, P. (2016). IBM SPSS statistics 23 step by step: A simple guide and reference. London: Routledge. https://doi.org/10.4324/9781315545899

Herrington, J., Reeves, T., \& Oliver, R. (2010). A guide to authentic e-learning. New York, NY: Routledge.

Higgins, S.J. (2003). Does ICT improve learning and teaching in schools? Nottingham: British Educational Research Association. Retieved from www.dysgu.llyw.cymru/ docs/learningwales/publications/121122ictlearningen.pdf

Hollingsworth, S. (1989). Prior beliefs and cognitive change in learning to teach American Educational Research Journal, 26(2), 160-189. https://doi.org/10.3102/ 00028312026002160

Koehler, M.J., \& Mishra, P. (2009). What is technological pedagogical content knowledge? Contemporary Issues in Technology and Teacher Education, 9(1), 60-70. Retrieved from https://citejournal.s3.amazonaws.com/wp-content/uploads/ 2016/04/v9i1general1.pdf

Kotrlik, J.W., \& Williams, H.A. (2003). The incorporation of effect size in information technology, learning, and performance research. Information Technology, Learning, and Performance Journal, 21(1), 1-17. Retrieved from https://pdfs. semanticscholar.org/e5c3/504ca4baef11c1cda8ec085833dbccb63259.pdf

Kramarski, B., \& Feldman, Y. (2000). Internet in the classroom: Effects on reading comprehension, motivation and metacognitive awareness. Educational Media International, 37(3), 149-155. https://doi.org/10.1080/09523980050184709.

Kuiper, E., \& De Pater-Sneep, M. (2014). Student perceptions of drill-and-practice mathematics software in primary education. Mathematics Education Research Journal, 26(2), 215-236. https://doi.org/10.1007/s13394-013-0088-1

Leendertz, V., Blignaut, A.S, Ellis, S., \& Nieuwoudt, H.D. (2015). The development, validation and standardisation of a questionnaire for ICT professional development of mathematics teachers. Pythagoras, 36(2), Art. \#297. https://doi.org/10.4102/ pythagoras.v36i2.297

Leendertz, V., Blignaut, A.S., Nieuwoudt, H.D., Els, C.J., \& Ellis, S.M. (2013). Technological pedagogical content knowledge in South African mathematics classrooms: A secondary analysis of SITES 2006 data. Pythagoras, 34(2), Art. \#232. https://doi.org/10.4102/pythagoras.v34i2.232

Liu, M-H., \& Kleinsasser, R. (2015). Exploring EFL teachers' knowledge and competencies: In-service program perspectives. Language Learning \& Technology, 19(1), 119-138. Retrieved from http://www.lltjournal.org/item/2891

Lundall, P., \& Howell, C. (2000). Computers in schools: A national survey of information communication technology in South African schools. Cape Town: Education Policy Unit, University of the Western Cape.

Marwan, A. (2008). An analysis of Australian students' use of information and communication technology (ICT). International Journal of Instructional Technolog \& Distance Learning, 5(11), Retrieved from http://itdl.org/Journal/Nov_08/ article05.htm

Mathews, J.G., \& Guarino, A.J. (2000). Predicting teacher computer use: A path analysis. International Journal of Instructional Media, 27(4), 385-392.

Michael, R.S. (2001). Crosstabulation \& chi square. Bloomington, IN: Indiana University. Retrieved from http://www.indiana.edu/ educy520/sec5982/week_12/chi_sq_ summary011020.pdf

Mishra, P., \& Koehler, M.J. (2006). Technological pedagogical content knowledge: A framework for teacher knowledge. Teacher College Record, 108(6), 1017-1054. https://doi.org/10.1111/j.1467-9620.2006.00684.x

Molnár, G. (2008). The use of innovative tools in teacher education: A case study. In D. Solesa (Ed.), Proceedings of the Fifth International Conference on Informatics, Educational Technology and New Media in Education (pp. 44-49). Retrieved from: http://www.staff.u-szeged.hu/ gymolnar/sombor_2.pdf

Moore, N.D. (2012). Alternative strategies for teaching mathematics. Education and Human Development Master's Theses (Paper 130). Retrieved from https:// digitalcommons.brockport.edu/ehd_theses/130/ 
Mueller, J., Wood, E., Willoughby, T., Ross, C., \& Specht, J. (2008). Identifying discriminating variables between teachers who fully integrate computers and discriminating variables between teachers who fully integrate computers and teachers with limited integration. Computers \&
https://doi.org/10.1016/j.compedu.2008.02.003

Mumtaz, S. (2000). Factors affecting teachers' use of information and communications technology: A review of the literature. Journal of Information Technology for Teacher Education, 9(3), 319-342. https://doi.org/10.1080/14759390000200096

Ndlovu, N., \& Lawrence, D. (2012, September). The quality of ICT use in South African classrooms. Paper presented at the Towards Carnegie III Strategies to Overcome Poverty and Inequality Conference, University of Cape Town, Cape Town.

Noor-UI-Amin, S. (2013). An effective use of ICT for education and learning by drawing on worldwide knowledge, research, and experience: ICT as a change agent for education. Scholarly Journal of Education, 2(4), 38-45. Retrieved from http:// www.scholarly-journals.com/sje/archive/2013/April/pdf/Noor-Ul-Amin.pdf

North, D., Gal, I., \& Zewotir, T. (2014). Building capacity for developing statistical literacy in a developing country: Lessons learned from an intervention. Statistics Education Research Journal, 13(2), 15-27. Retrieved from http://iase-web.org/ documents/SERJ/SERJ13\%282\%29_North.pdf

North, D., \& Scheiber, J. (2008). Introducing statistics at school level in South Africa: The crucial role played by the national statistics office in training in-service teachers. In C. Batanero, G. Burrill, C. Reading, \& A. Rossman (Eds.), Proceedings of the 18th ICMI Study Conference and 2008 IASE Round Table Conference. Voorburg, The Netherlands: International Statistical Institute and International Commission on Mathematical Instruction. Retrieved from http://www.ugr.es/ icmi/iase_study/ Files/Topic6/T6P2_North.pdf

O'Dwyer, L., Russell, M., \& Bebell, D. (2003). Elementary teachers' use of technology: Characteristics of teachers, schools, and districts associated with technology use. Boston, MA: Technology and Assessment Study Collaborative, Boston College.

O'Dwyer, L., Russell, M., \& Bebell, D.J. (2005). Identifying teacher, school and district characteristics associated with elementary teachers' use of technology: A multilevel perspective. Journal of Educational Computing Research, 33(4) 369-393. https://doi.org/10.2190/4BVW-5NDJ-L2G3-EAND

Palak, D., \& Walls, R.T. (2009). Teachers' beliefs and technology practices: A mixedmethods approach. Journal of Research on Technology in Education, 41(4), 417-441. https://doi.org/10.1080/15391523.2009.10782537

Purcell, K., Heaps, A., Buchanan, J., \& Friedrich, L. (2013). How teachers are using technology at home and in their classrooms. Washington, DC: Pew Research Center Retrieved from http://www.pewinternet.org/files/old-media//Files/Reports/2013/ PIP_TeachersandTechnologywithmethodology_PDF.pdf

Remesh, A. (2013). Microteaching, an efficient technique for learning effective teaching. Journal of Research in Medical Sciences, 18(2), 158-163. Retrieved from https://www.ncbi.nlm.nih.gov/pmc/articles/PMC3724377/
Sabzian, F., \& Gilakjani, A.P. (2013). Teachers' attitudes about computer technology training professional development, integration, experience, anxiety, and literacy in English language teaching and learning. International Journal of Applied Science and Technology, 3(1), 67-75. Retrieved from http://ijastnet.com/journals/Vol_3 and Technology, 3(1), 67-75.
No_1_January_2013/9.pdf

Sorto, M.A., \& Lesser, L. (2009). Towards measuring technological pedagogical content knowledge in statistics: Middle school teachers using graphing
calculators. Proceedings of the 2009 IASE Satellite Conference, Durban, South calculators. Proceedings of the 2009 IASE Satellite Conference, Durban, South
Africa. Retrieved from https://www.stat.auckland.ac.nz/ iase/publications/ sat09/5_1.docx

South Africa Institute of Race Relations. (2015). Education report. Johannesburg: SAIRR.

Tasir, Z., Abour, K.M.E.A., Halim, N.D.A., \& Harun, J. (2012). Relationship between teachers' ICT competency, confidence level, and satisfaction toward ICT training programmes: A case study among postgraduate students. The Turkish Online programmes: A case study among postgraduate students. The Turkish Online
Journal of Educational Technology, 11(1), 138-144. Retrieved from http://www. Journal of Educational Technology,
tojet.net/articles/v11i1/11112.pdf

Tishkovskaya, S., \& Lancaster, G.A. (2012). Statistical education in the 21st century: A review of challenges, teaching innovations and strategies for reform. Journal of Statistics Education, 20(2), 1-55. https://doi.org/10.1080/10691898.2012.11 889641

Umugiraneza, O., Bansilal, S., \& North, D. (2016). Teachers' confidence and beliefs in teaching mathematics and statistics concepts. International Scientific Researches Journal, 72(09), 1-16.

Umugiraneza, O., Bansilal, S., \& North, D. (2017). Exploring teachers' practices in teaching mathematics and statistics in KwaZulu-Natal schools. South African Journal of Education, 37(2) Art. \#1306, 13 pages. https://doi.org/10.15700/saje. v37n2a1306

Umugiraneza, O., Bansilal, S., \& North, D. (2018a). Investigating teachers' formulations of learning objectives and introductory approaches in teaching mathematics and statistics. International Journal of Mathematical Education in Science and Technology, 1-17. https://doi.org/10.1080/0020739X.2018.1447150

Umugiraneza, O., Bansilal, S., \& North, D. (2018b). Exploring teachers' descriptions of 'ways of working with the curriculum' in teaching mathematics and statistics. African Journal of Research in Mathematics, Science and Technology Education, 22(1), 70-80. https://doi.org/10.1080/18117295.2018.1445496

Van Melle, E., \& Tomalty, L. (2000). Using computer technology to foster learning for understanding. Journal of Microbiology \& Biology Education, 1(1), 7-13. https:// doi.org/10.1128/154288100X14285805587224

Yang, Z. (2013). Transforming K-12 classrooms with digital technology. Hershey, PA: Information Science. 